\title{
A Multiplicity of Regionalisms in Southeast Asia
}

\author{
ChaRmaine MisaluChA*
}

Regional arrangements in Southeast Asia (SEA) beg the question of why this "alphabet soup" exists. This can be addressed by looking at a wider context: these regionalisms are not merely SEA states' responses to international events, nor are they solely projections of independence/self-assertion. Instead, SEA's ventures demonstrate Constructivist logic: Southeast Asian states shape and are themselves shaped by the historical and geographical circumstances in which they find themselves. Beginning with the assumption that international relations are fluid and mutually constitutive, SEA regionalisms can be explained by complex engagement, as seen in the evolution of ASEAN and the dynamics of the APT and the EAS. In short, this paper argues that the multiplicity of regionalisms in Southeast Asia is a reflection of Constructivism at work.

Keywords: ASEAN, ASEAN Plus Three, East Asia Summit, Regionalism, Southeast Asia

*Assistant professor, De La Salle University; E-mail: charmaine.misalucha@dlsu.edu.ph 


\section{INTRODUCTION}

Regionalism has been an interesting phenomenon in the universe of International Relations. Current scholarship is predicated on whether regions are derived from physical or security/functional conceptualizations (Fawcett and Hurrell 1995; Mansfield and Milner 1999). How are regions defined? How are they created? How are they best organized? Via political-military lines or via functional arrangements? How are they transformed? Consequently, a methodological divide persists between Rationalist and Constructivist research programs. On one hand, the material delineation of regions is concentrated on studies about intra- or interregional trade (Frankel 1997 and 1998). On the other hand, the Constructivist agenda-at least, the Wendt variant-emphasizes the role of norms and ideas in the creation and evolution of regions (Adler 1997; Murphy 1991).

Complementing these rich theoretical debates are interesting cases of regionalism in the empirical plane. Southeast Asia alone has been characterized by a multiplicity of regionalisms since the 1960s. From the Association of Southeast Asia (ASA) emerged the Association of Southeast Asian Nations (ASEAN), which today forms the backdrop of adjunct sub-regional and/or extra-regional organizations. For instance, since the Cold War, ASEAN has managed to secure dialogue partnerships with the United States, Russia, Australia, China, and the European Union, among others. Moreover, it has created the ASEAN Regional Forum (ARF), the ASEAN Plus Three (APT) framework and the East Asia Summit (EAS), engaged in the Asia-Pacific Economic Cooperation (APEC), the ASEAN Free Trade Area (AFTA) and a variety of bilateral free trade agreements with Australia and New Zealand, India, China, Japan, and South Korea, and most recently embarked on the formation of the ASEAN Community. Given the multiple layers of regional entities that are currently in operation in Southeast Asia today, these beg the question of why this "alphabet soup" of arrangements exists. In other words, why does Southeast Asia embark on various regional projects? What explains this multiplicity?

This question can be addressed by looking at a wider context, i.e., that these regionalisms are not merely Southeast Asian states' responses to international events, nor are they solely projections of independence or self-assertion by middle or lesser powers in the international scene. The question cannot be addressed by making references to binary oppositions. Instead, Southeast Asia's ventures into multiple regionalisms are a demonstration of the dynamics of Constructivism: Southeast Asian states shape, and at the same time, they are themselves shaped by the historical and geographical circumstances in which they find themselves. Beginning with the assumption that international relations are fluid and intersubjective, Southeast Asian regionalisms can be explained by complex engagement, and this is exhibited by looking at the evolution of ASEAN, as well as the 
dynamics of the APT and the EAS. I choose to focus on the APT and the EAS because not only do they include the major regional powers (China and Japan), but they also maintain that ASEAN is central in these arrangements. In line with this, I argue that the multiplicity of regionalisms in Southeast Asia is a reflection of Constructivism at work.

The central question posed in this paper is germane for two reasons. First, it is often voiced that ASEAN is nothing short of a "talk shop," that Southeast Asia's adventurism in regionalism efforts preclude, or at least hamper, the attainment of the ultimate goal of integration. It is easy enough to claim that these varying regional arrangements are how regionalism is done in the non-Western part of the post-colonial world, so it does not matter much whether integration is achieved in the end. However, what I hope to achieve here is that explaining and understanding Southeast Asia's multiple regionalisms present a certain fluidity, an ongoing project rather a defined and finished one. An appreciation of such nuances makes for a more careful, even sensible, evaluation of whether Southeast Asian regionalisms are a success or a failure.

Second, the question is also significant from an academic perspective. The study of Southeast Asian regionalism is vibrant in that scholars approach the subject from different theoretical leanings. While many are actively involved in the Rationalist-Constructivist debate mentioned earlier, very few studies venture beyond that. Constructivist thought (both the "mainstream" and "critical" variants) is rarely used as a framework. Thus, asking why Southeast Asia embarks on a multiplicity of regional projects provides a platform for a different school to be engaged in current scholarly debates about the region.

In view of the above, I account for the multiplicity of regionalisms in Southeast Asia by looking at Constructivism's contributions at various levels: the more formal level of academic inquiry is translated and is thus applied in the more practical level of the day-to-day running of regional efforts and affairs. Hence, the first part offers a theoretical take on Constructivist thinking, and presents the two variants of this school of thought. From here, the notions of the fluid nature of international relations, the co-constitution of agents and structures, and complex engagement are extrapolated and thereafter applied in the second part of the paper. Taking a historical approach in regionalisms in Southeast Asia discloses the role of extra- and intra-regional factors in the crafting of current regional arrangements.

\section{CONSTRUCTIVISM IN INTERNATIONAL RELATIONS}

In order to account for the multiplicity of regionalisms in Southeast Asia, consideration must be paid to Constructivism's contributions to the academic inquiry of International Relations. This school of thought questions some of the basic tenets of the field, and offers alternative ways of viewing the world. Here, 
the two variants of Constructivism are discussed and emphasizes three important contributions: the fluid nature of international relations, the co-constitution of agents and structures, and complex engagement. These concepts are then applied to Southeast Asian regionalism in the next part of the paper.

\section{Two Strands: "Mainstream" and "Critical"}

With the end of the Cold War, Constructivism emerged as a school of thought in International Relations. Ontologically, it claims that agents and structures are constitutive of each other. This is to say that while interactions between agents are social in nature, structures also shape the interests and identities of said actors (Frederking 2003). There are two strands of Constructivism in International Relations: one is popularized by Alexander Wendt and Peter Katzenstein, which focuses on the notion of ideas, while the other is advocated by the likes of Nicholas Onuf and Friedrich Kratochwil, which takes as its starting point Ludwig Wittgenstein's linguistic turn and therefore focuses on language and speech acts, and also on rules and norms.

Wendt's thought can be traced to his desire to address the agent-structure problem: do human beings change the society they inhabit, or is it society that determines the actions of agents? In criticizing Neo-Realism and World-Systems theory for granting primacy to either agents or structures, Wendt (1987) proposes approaching the problem via Structuration, which grants equal ontological status to the two. Others have also contributed to the agent-structure debate. David Dessler builds on it by suggesting that "positional" and "transformational" models of international structure can expand Waltz's theory (1989). Walter Carlsnaes likewise joins the debate by focusing on foreign policy analysis (1992). Meanwhile, Jeffrey Berejikian (1992) offers the concept of framing as the solution to the problem, which suggests that agents make different decisions when in different structures, and Philip G. Cerny (2000) advocates looking at different categories of agents in order to more comprehensively account for longer-term change. Critics like Roxanne Lynn Doty (1997) and Colin Wight (1999 and 2006) may have pointed out the loopholes in the "solutions" the above scholars have offered to the agent-structure problem, but the debate continues. Indeed, Andreas Bieler and Adam David Morton may just be correct in saying that "the problem of agencystructure may well be a Gordian knot that cannot be unraveled or solved" $(2001,5)$.

Wendt's 1987 work on the agent-structure problem branched out into his "Anarchy is What States Make of It" article (1992), and eventually into a fullblown book entitled Social Theory of International Politics (1999). Generally resting on three points, Wendt's Constructivism relies on intersubjective knowledge (i.e., that ideas, norms, and values that actors hold are shared amongst them), the process of socialization that makes both agents and structures co-constitutive 
and co-determinative of each other, and the possibility of change: "Structures are not reified objects that actors can do nothing about $\cdots$. Rather structures exist only through the reciprocal interaction of actors. This means that agents, through acts of social will, can change structures" (Copeland 2006, 3). Despite the merits of Wendt's contribution to Constructivism in International Relations, his version of it is problematic because of the inability to identify how co-constitution begins. In contrast, the other variant of Constructivism addresses this shortcoming by paying attention to language.

Onuf's variant of Constructivism is referred to as rule-oriented Constructivism (ROC) (Copeland 2006). The premises are as follows (Burch 2000). First, social creation is the ongoing co-constitution of, on one hand, agents and social arrangements, and material conditions and ideas, on the other. Second, considered as the "bedrock" of ROC, such co-constitution is achieved through speech acts and rules. Third, regulative and constitutive rules do not differ. Fourth, change is the necessary outcome of the continuing process of social construction. Fifth, rules give rise to rule where advantages are distributed unequally. This paves the way for the final premise, which posits that this uneven distribution of advantages (resources) results in three types of rule: hegemony, hierarchy, and heteronomy. This is the foundation of the paradigm of rule.

\section{Fluidity, Co-Constitution, and Complex Engagement}

The distinctions between the two variants notwithstanding, both camps share the view that international relations are fluid. Fluidity here refers to the contingency of structures and behaviors. Fluidity entails that assumptions and concepts are not-and should not-be taken as given. It highlights the ongoing creation, recreation, negotiation, and re-negotiation of international relations. In these interactions, fluidity presupposes the active role that units or agents, rather than the structure, play. Logically, it follows that actors themselves determine how they interact with whom and how. In this sense, fluidity implies the possibility of change in the international system. Most importantly, fluidity makes possible the escape from, and even the non-necessity, of the agent-structure problem mentioned above.

To reiterate, at the crux of the agent-structure debate in the field of International Relations is the question of power: can the agent operate independent of the structure, or does the structure determine the behavior of the agent? Constructivism offers a way out of the dilemma. Rather than highlighting that agents and structures are independent of each other (and consequently, that one has power over the other), Constructivism assumes the co-constitution of agents and structures, i.e., that they are interdependent rather than independent. Co-constitution, therefore, stems from and is only possible so long as we start from the premise 
that international relations are fluid. In other words, co-constitution is the logical by-product of fluidity.

It is against this backdrop that the notion of complex engagement emerges. Given the fluid nature of international relations and the mutually constitutive character of agents and structures, complex engagement sheds light on the multiplicity of interactions (economic, political, social; informal, formal; bilateral, multilateral) on a variety of issues. What makes complex engagement complex is that it is an ongoing, two-way, social process of action and interaction that involves persuasion and the ultimate aim of creating cooperative relations by finding new and shared areas of agreement ( $\mathrm{Ba}$ 2006). Complex engagement thus connotes that international relations are fluid, contingent, and flexible. The twoway social process depicts the fact that actors' perception of themselves and behavior towards others affect and are affected by the structures they create in their interactions. In the context of our argument here, complex engagement can be understood as interactions between and among actors or agents vis-à-vis the structures they create and recreate in the course of their relations. These three Constructivist tenets play into the dynamics of Southeast Asian regionalism, as well as in the APT and the EAS. The next part looks at Constructivism as applied in Southeast Asian regionalism.

\section{CONSTRUCTIVISM IN SOUTHEAST ASIA}

The workings of Constructivism, particularly the concepts of fluidity, mutual constitution, and complex engagement are seen in the regional efforts of Southeast Asia. I posit that 1997 is a turning point not least because of the Asian financial crisis, but also because this spurred the region into forming the APT and the EAS. The following discussion forwards that even when Constructivism has not yet significantly taken root in International Relations in pre-1997 Southeast Asia, traces of fluidity, mutual constitution, and complex engagement are already apparent and more so, therefore, in the post-1997 period.

\section{Pre-1997 Regional Efforts}

Extant literature on pre-1997 regional efforts can be plotted on two axes. On one hand, emphasis is placed on the role of external actors in the creation and maintenance of arrangements in the region. An underlying idea herein is that since efforts have been spurred by extra-regional actors, the result is that regionalisms overlap with each other and render some (or most) redundant. On the other hand, another body of literature highlights that these regional arrangements are due to the active role played not by outside powers but by the Southeast Asian states themselves. While granting agency to the small states, however, works in this 
category hint that the ultimate goal of integration is still very far off. These two poles in the literature suggest that extra- and intra-regional factors contributed to the Southeast Asian arrangements that we have today. Both also lend credence to our earlier premise that the moves and counter-moves of actors showcase the fluid as well as the mutually constitutive character of their relations with each other. Furthermore, an examination of extra- and intra-regional factors in the evolution of Southeast Asian regional arrangements attests to the presence and operation of complex engagement: the numerous regional arrangements, after all, are exercises in finding different areas of agreement.

Some studies argue for the weight of extra-regional factors in advancing regionalism. Donald K. Emmerson remarks that the idea of "Southeast Asia" became more visible only after World War II and was only thereafter given political connotation (1984). This is also Tim Huxley's point when he characterizes Southeast Asia's international relations in the 1960s and the 1970s as being dominated by Western scholarship, advocated and studied by non-Southeast Asian scholars, and concerned primarily with regional security and the strategic utility of the region (1996). Indeed, Philip Charrier argues that the Southeast Asian region has been first and foremost a creation of Western academia, which has been subsequently perpetuated by the Cold War (2001). Furthermore, James Tyner goes so far as to argue that the idea of a Southeast Asian region is imagined, created, and perpetuated to serve American political, economic, territorial, and moral interests (2007). The same stance is implicit in Evelyn Colbert's work, which focuses on Southeast Asia from World War II to the Vietnam War, and describes how the region has become entangled in the East-West conflict of the Cold War (1977). As the Cold War progressed, Southeast Asia became increasingly seen as merely a function of the American strategy of containment (Dreisbach 2004). Corollary to this, Werner Levi points out that Southeast Asia has become important to the United States because of the rise of Communist China (1968). The impact of the communist threat was examined more closely through the Vietnam War, as Michael Leifer does. Focusing on regional conflict, he identifies the interests and roles of external powers and regional states in the Vietnam War (1980).

When regionalism gained ground in Southeast Asia in the 1960s, studies still reflected the weight of extra-regional factors in general, and the United States in particular. Arnfinn Jorgensen-Dahl, for instance, makes clear the gravity of the influence of the external environment in prodding Southeast Asia to form regional organizations (1982). Moreover, Leifer traces the evolution of ASEAN and embeds his analysis in Cold War politics (1989). The US, meanwhile, seemed to welcome the idea of regionalism because the "ideological underpinnings" of regional cooperation called "for a continued US presence and involvement in East and Southeast Asia ..." (Pollard 1970, 255). Chintamani Mahapatra synthesizes the significance of the American influence in the formation of ASEAN: "ASEAN 
was the product of Asian initiative. But it was hardly an Asian creation. Behind the Asian initiative was the American 'support' and 'discreet guidance.' Washington almost acted like a mid-wife in the birth of ASEAN" (1990, 6-7).

Regardless of the end of the Cold War in the 1990s, the strategic sphere still played a major role in the literature. In the wake of the East-West conflict, however, it seemed apparent that Asia in general slid down the US agenda. Richard K. Betts highlights this fact (1993-1994). Despite this, American dominance in the region is still necessary. Paul Dibb justifies US presence in Asia thus, "The middle powers will want power balanced in the region, hence their continuing interest in a US presence. Only the US can ensure that dangerous power symmetries do not emerge (1995, 71)."

Perhaps it is because of this that scholars in Southeast Asia clamor for the necessity of American hegemony in the region. Nicholas Khoo and Michael L. Smith point out that conceptions of a Concert of Asia would not be feasible. Instead, a clear pecking order led by the United States would be what is needed for preserving order in Asia (2002). Vedi Hadiz likewise underscores the dominance of the United States in his edited volume Empire and Neoliberalism in Asia (2006). In the same volume, Goran Thereborn conceives world power as a multilateral configuration, with the US at the head (2006). Furthermore, David A. Lake in a 2006 article imbues the US with an "authority of practice" from which it draws its hegemony. Other calls for keeping the US in the region include Mark Beeson who acknowledges that there are resistances to American hegemony. Nonetheless, these resistances are stanched because the US is becoming more and more unilateral (2004a). Moreover, these resistances would seem futile insofar as Southeast Asia is concerned because the region is still subjected to external issues (2004b).

Southeast Asia and the United States may now be more mindful of the "gaps" in their relationship, according to Satu P. Limaye, but this is only largely due to the structure created by the US (2004). Southeast Asia, at least insofar as the literature on this side of the spectrum projects, is therefore still left with no agency and no activism in the way it shapes its relationship with an external great power. Perhaps the United States' dominance and influence in Southeast Asia is, as Robert J. McMahon intimates, a reflection of American society and values (2004). But as traditional Realists would argue, the presence of a great power, external or otherwise, in a region is only typical of international relations. Smaller powers would just have to learn to accept that fact (De Castro 2000).

Hence, the multiplicity of regional organizations in Southeast Asia, at least insofar as the literature is concerned, is due to the continuing presence and influence of extra-regional players, particularly the United States. At the same time, this multiplicity can also be due to the fact that Southeast Asia is not the West, so it logically follows that the former's experiments, so to speak, with regionalism are different. It follows that this theme has the objective of infusing 
agency to the smaller states of Southeast Asia. Such a theme has also been recurrent from the 1960s to the present period. At the height of the Cold War in Asia, Bernard K. Gordon draws attention to political conditions within the region, as opposed to the more general works that deal with Southeast Asia's involvement in the Cold War via the Vietnam War, which end up analyzing regional politics through the lenses of the external great powers (1966). Granted that Gordon might have been making policy recommendations to the United States, but his proposals for American withdrawal take account of intricate regional politics by focusing on the domestic problems facing the Southeast Asian states, and by highlighting issues pervading intra-regional relations (1969). Robert C. Horn points to renewed US interest in Southeast Asia, which is brought about by the 1978 Vietnamese invasion of Kampuchea and which eventually pushed the smaller states to learn to play ball with the bigger powers (1985). Focusing particularly on ASEAN, Donald E. Weatherbee suggests that regionalism is Southeast Asia's way of keeping the United States in the region and dealing with changing balances of power (1978). This is also the point of Sheldon W. Simon's observation: that ASEAN is a way of balancing, and that Southeast Asia constrains and manipulates great power policies to serve the goals of "indigenous states" (1982 and 1983).

In the post-Cold War era, the theme resurfaces. Evelyn Goh also advocates Southeast Asia's activist initiatives in engaging the United States. She demonstrates that Southeast Asia's strategies of omni-enmeshment and complex balancing result in a hierarchical order that appears to be akin to the Gramscian notion (2005b and 2007-2008). Granted that the hierarchic order entails that the United States be on top, it is nonetheless "hegemony by consent" because the US is exactly where the Southeast Asian states want it to be. Furthermore, in her edited monograph Betwixt and Between: Southeast Asian Strategic Relations with the US and China, she argues that Southeast Asian states are "hedging their bets using a range of policies that have some countries leaning more to one side, but still pursuing options with the other side" (2005a, 6-7). This thus seems to suggest that while US presence in the region is necessary, such presence is only at the behest of Southeast Asia. Amitav Acharya and See Seng Tan's argument, meanwhile, rests on the shortcomings of the logic of the balance of power, particularly as applied to the US role in Southeast Asia (2006). They emphasize the fact that the security architecture of Southeast Asia does not rest entirely on American presence and influence. Drawing from historical and contemporary instances, they prove that ASEAN has contributed greatly to the current state of regional politics. David Capie also grants agency to Southeast Asia vis-à-vis its relations with the United States (2004). He argues that rather than balancing against or bandwagoning with the United States, the Southeast Asian states instead practice a "mix of cooperation and constraint in bilateral ties" (223). The cases of Indonesia, Malaysia, and the Philippines showcase that these regional states are pragmatic in their response. 
Furthermore, domestic politics played a considerable role in the states' stance.

Hence, these works highlight the active role of Southeast Asian states in the maintenance of security in the region. Considering that both extra- and intraregional players have been involved in the creation and perpetuation of the current regional architecture in Southeast Asia, it can indeed be posited that the nuances of regional efforts are a reflection of prior to the formation of the APT and the EAS reflect the Constructivist logics of fluidity, co-constitution, and complex engagement. The same concepts are apparent in the wake of the 1997 Asian financial crisis.

\section{Post-1997 Regional Efforts}

It must be kept in mind that in both variants of Constructivism, i.e., the "mainstream" version of Wendt and the "critical" take of Onuf, a central theme is the active engagement of agents and structures, and hence the mutually constitutive character of international relations. The interplay of agents and structures can thus be observed in the deft diplomatic wrangling that the ASEAN states and key players outside the region employed in the APT and the EAS. While it is true in the case of the APT that regional efforts were precipitated by extra-regional developments and that prior decisions or actions regarding crises in the past limited or directed the range of options with which to address current problems, the Constructivist notion of complex engagement was nonetheless at work. The catalyst of the creation of the APT was the 1997 Asian financial crisis. As has been discussed elsewhere in the literature, the 1997 crisis transformed Asia in three ways (Komori 2009). First, it clearly undermined the credibility of the International Monetary Fund (IMF). Second, it called into question the effectiveness of existing regional institutions, which, and this is the third factor, prompted leaders to realize the importance of drafting measures to deal with the negative consequences of market activities.

Against this backdrop, the idea behind the APT was to ensure that member states would be able to hedge against future economic shocks. The mechanisms were further expanded in the form of the Chiang Mai Initiative, which included an Expanded ASEAN Swap Arrangement and a Network of Bilateral Swap Arrangements (Caballero-Anthony 2009). The APT thus became part of Asia's multilevel governance in the post-Cold War world (Thomas 2009). Arguably therefore, while the 1997 crisis undermined some of ASEAN's regional efforts, it likewise stirred calls for reform and reinvention (Acharya 2009). While we may posit that the APT was simply a knee-jerk reaction to the 1997 crisis (in a way, it was), its creation and succeeding actions spell ongoing negotiations between agents and structures. Seen this way, we may therefore argue that the formation of the APT, of which China is a crucial actor, embodies Constructivist arguments about socialization, 
specifically that of complex engagement.

A good example of complex engagement at work is the socialization of both ASEAN and China, which became the springboard for the establishment of the APT (Ba 2006). The end of the Cold War was a period of transition for East and Southeast Asia: it shifted attention to East Asia's export-oriented economic dynamism, lifted Cold War divisions, highlighted concerns over US withdrawal from the region, and necessitated the need for cooperative security arrangements to supplement the hub and spokes system (Cook 2008). In spite of the uncertainty in the immediate post-Cold War period, ASEAN and China managed to get involved multilaterally and bilaterally. ASEAN began by expanding the Post-Ministerial Conferences to include new dialogue partners. In particular, the Post-Ministerial Conferences became the basis for the ARF, as well as for the Asia-Europe Meeting (ASEM), APEC, and the APT. Bilaterally, ASEAN and China held consultations between senior officials, joint cooperation meetings, ASEAN-China summits, and implemented the ASEAN Plus China framework alongside the APT process. The context and process of ASEAN and China's complex engagement therefore rested on recognizing commonalities, ASEAN's unique brand of regionalism, and a relatively stable regional balance of power for reinforcement (Ba 2006). In this sense, ASEAN's engagement of China has been relatively successful, particularly since China is partial to the APT as the main venue for building an East Asian community, given that it provides a framework to promote regional cooperation at multiple levels (multilateral and bilateral) as well as helps improve political relations (Wu 2009). In sum, the socialization process that ASEAN and China underwent in the wake of the end of the Cold War paved the way for the launch of the APT in 1997. The co-constitution of agents and structures is demonstrated in ASEAN's and China's actions prior to and after the 1997 crisis, which precipitated the formation of the APT framework. Problems, however, emerged in the form of the issues surrounding the East Asia Summit.

While the APT was a response to the financial crisis in 1997, the EAS was a reaction to the rise of China (Cook 2008). The origins of the EAS were first raised in a report of the East Asia Vision Group, which was submitted to the summit meeting of the APT in 2001. The report recommended the evolution of the annual APT summit into the EAS as a means to build the East Asia Community (Kim 2010). Malaysia pushed for the early transformation of the APT, as evidenced by Prime Minster Badawi's 2004 visit to Beijing to promote the creation of the EAS. Badawi reasoned that the transformation of the APT to the EAS could be an attempt to strengthen an East Asia-only organization, and could balance the North American Free Trade Area and the European Union.

China welcomed Malaysia's move for several reasons (Kim 2010). First, it wanted to increase its influence by strengthening regional cooperation. Second, regional rivalry propelled China to push for an exclusive regional grouping. Third, 
it hoped to replace American strategic preponderance in the region. Its growing influence is thus seen in the evolution of the East Asian Economic Group into the APT, and the enhancement of the process through its elevation to the EAS. In so doing, China insisted that only states could participate in the APT. By implication, Hong Kong and Taiwan could not be members (Cook 2008). Meanwhile, Japan pushed for the expansion of the EAS' membership to include Australia, New Zealand, and India.

China's objective in keeping the EAS largely confined to APT countries is to maintain its economic clout and central position. It was however, constrained by competition from Japan and ASEAN's insistence on maintaining a leadership role in regional cooperation (Kim 2010). In order to set its preference in motion, China exerted influence on ASEAN by exploiting the growing relations between them, i.e., via economic cooperation. However, ASEAN chose to allow non-regional powers to participate in the EAS. In short, ASEAN recognized the need to develop the EAS as a hedge against Chinese domination. With this end in mind, ASEAN determined the participation requirements to the EAS. Specifically, membership is dependent on being an ASEAN dialogue partner, and on being a signatory to ASEAN's Treaty of Amity and Cooperation. This clever diplomatic maneuverplaying up the competition between China and Japan-ensured ASEAN's central role. At the same time, it also maintained the traditional strategy of building good relations with all major powers, an argument not unheard of in the literature (Goh 2011).

In summary, the moves and counter-moves that ASEAN, China, and Japan made in the context of the EAS showcase-again-the fluid nature of international relations. Agents and structures are mutually constituted; one is not an a priori function of the other. While it is true that political integration is still far off in the vicinity of Southeast Asian regionalism, ASEAN states nonetheless managed to "tame" great powers through the careful crafting and maintenance of the balance of power among them, and through the creation of international institutions (Webber 2010; Goh 2011). ASEAN, in short, succeeded in its "brokerage" role, albeit in a limited fashion. For one, it is not able to transform the nature of triangular relations among the United States, China, and Japan. It has also been complicit in extending US security dominance so long as Washington is seen as a benign external guarantor. Furthermore, ASEAN's "brokerage" role offered great powers a platform for continuing their so-called avoidance strategies: the ASEAN Way, which was critical to the socialization of China, is now used to stall the development of other norms, as in the case of the ARF. In short, many hard cases of regional security conflicts are swept under the proverbial rug. Finally, ASEAN's limited "brokerage" role is seen in the fact that great powers revert to a balancing mindset and behavior-as in the case of the disagreement over membership in the EAS: China and Japan compete for symbolic leadership. However the story plays out, multiple 
arrangements in Southeast Asia are a testament to the unique means of regionalism in the global south. Likewise, Southeast Asian regionalisms also demonstrate the ongoing process of complex engagement.

\section{CONCLUSION}

At the outset, this paper posed the question why a multiplicity of regional arrangements exists in Southeast Asia, and these were accounted for in this paper as reflections of the Constructivist notions of fluidity, mutual constitution, and complex engagement. The APT and the EAS are just two among the many regional arrangements currently at play in Southeast Asia, and they are indeed manifestations of how small states craft their regional security architecture, i.e., by binding outside powers in. Likewise, the APT and the EAS are tangible proof of theoretical arguments relating to the co-constitution of agents and structures. While these accounts for the wide variety of regionalisms in Southeast Asia, critics may be right to point out that these experiments make the ultimate goal of integration seem even farther away. Still, perhaps what the Southeast Asian experience offers is that the path to integration can take forms other than the ones already taken by other regions.

Southeast Asian regionalism highlights two other points. First, the either-or distinctions that we often find in discussions academic or otherwise are clearly called into question here. Typically, it is posited that either the ASEAN experiment is a success (meaning that it is moving toward a clearly delineated and linear way towards integration, European Union-style), or its multiple and overlapping arrangements are akin to the flailing actions of a drowning person. Binary distinctions, however, offer at best simplistic portraits. As both the APT and the EAS demonstrated, regional efforts are laced with nuances. Notions of "success" or "failure" must therefore be seen in shades of gray.

Second, moving above and beyond binary oppositions requires the utilization of less traditional approaches to understanding and explaining international relations. This is a welcome move, of course, as critical scholarship opens new research avenues along the lines of postcolonialism. The hyphen in "postcolonialism" is omitted to mean the unique circumstances that states finds themselves in after achieving independence. In this sense, Southeast Asian regionalism becomes a prime example of postcolonial community building. This, in itself, is the global south at work.

\section{REFERENCES}

Acharya, Amitav. 2009. The Strong in the World of the Weak: Southeast Asia in Asia's Regional Architecture In Asia's New Multilateralism: Cooperation, 
Competition, and the Search for Community, eds. Michael J. Green and Bates Gill. New York: Columbia University Press.

Acharya, Amitav and See Seng Tan. 2006. Betwixt Balance and Community: America, ASEAN, and the Security of Southeast Asia. International Relations of the Asia-Pacific 6(1): 37-59.

Adler, Emmanuel. 1997. Imagined (Security) Communities: Cognitive Regions in International Relations. Millennium: Journal of International Studies 26(2): 249-277.

Ba, Alice. 2006. Who's Socializing Whom? Complex Engagement in Sino-ASEAN Relations. The Pacific Review 19(2): 157-179.

Beeson, Mark. 2004a. US Hegemony and Southeast Asia: The Impact of, and Limits to, US Power and Influence. Critical Asian Studies 36(3): 445-462.

Beeson, Mark. 2004b. The United States and Southeast Asia: Change and Continuity in American Hegemony. In Asian Regional Governance: Crisis and Change, ed. Kanishka Jayasuriya. London: Routledge.

Berejikian, Jeffrey. 1992. Revolutionary Collective Action and the Agent-Structure Problem. The American Political Science Review 86(3): 647-657.

Betts, Richard K. 1993-1994. Wealth, Power, and Instability: East Asia and the United States After the Cold War. International Security 18(3): 34-77.

Bieler, Andreas and Adam David Morton. 2001. The Gordian Knot of AgencyStructure in International Relations: A Neo-Gramscian Perspective. European Journal of International Relations 7(1): 5-35.

Burch, Kurt. 2000. Changing the Rules: Reconceiving Change in the Westphalian System. International Studies Review 2(2): 181-210.

Caballero-Anthony, Mely. 2009. Evolving Regional Governance in East Asia: From ASEAN to an East Asian Community. In Governance and Regionalism in Asia, ed.Nicholas Thomas. New York: Routledge.

Capie, David. 2004. Between a Hegemon and a Hard Place: The "War on Terror" and Southeast Asian-US Relations. The Pacific Review 17(2): 223-248.

Carlsnaes, Walter. 1992. The Agency-Structure Problem in Foreign Policy Analysis. International Studies Quarterly 36(3): 245-270.

Cerny, Philip G. 2000. Political Agency in a Globalizing World: Toward a Structurational Approach. European Journal of International Relations 6(4): 435-463.

Charrier, Philip. 2001. ASEAN's Inheritance: The Regionalization of Southeast Asia: 1941-61. The Pacific Review 14(3): 313-338.

Colbert, Evelyn. 1977. Southeast Asia in International Politics, 1941-1956. Ithaca and London: Cornell University Press.

Cook, Malcolm. 2008. The United States and the East Asia Summit: Finding the Proper Home. Contemporary Southeast Asia 30(2): 293-312.

Copeland, Dale C. 2006. The Constructivist Challenge to Structural Realism: A 
Review Essay. In Constructivism and International Relations: Alexander Wendt and His Critics, eds. Stefano Guzzini and Anna Leander. London and New York: Routledge.

De Castro, Renato Cruz. 2000. Managing 'Strategic Unipolarity': The ASEAN States' Responses to the Post-Cold War Regional Environment. In Southeast Asian Perspectives on Security, ed. Derek da Cunha. Singapore: Institute of Southeast Asian Studies, 2000.

Dessler, David. 1989. What's at Stake in the Agent-Structure Debate? International Organization 43(3): 441-473.

Dibb, Paul. 1995. Towards a New Balance of Power in Asia, Adelphi Paper 395. Oxford: Oxford University Press.

Doty, Roxanne Lynn. 1997. Aporia: A Critical Exploration of the Agent-Structure Problematique in International Relations Theory. European Journal of International Relations 3(3): 365-392.

Dreisbach, Kai. 2004. Between SEATO and ASEAN: The United States and the Regional Organization of Southeast Asia In The Transformation of Southeast Asia: International Perspectives on Decolonization, eds. March Frey, Ronald W. Pruessen, and Tan Tai Yong. Singapore: Singapore University Press, 2004. Emmerson, Donald K. 1984. 'Southeast Asia': What's in a Name? Journal of Southeast Asian Studies 15(1): 1-21.

Fawcett, Louise and Andrew Hurrell, eds. 1995. Regionalism in World Politics: Regional Organization and International Order. Oxford: Oxford University Press.

Frankel, Jeffrey A. 1997 Regional Trading Blocs in the World Economic System. Washington, DC: Institute for International Economics.

Frankel, Jeffrey A. 1998. The Regionalization of the World Economy. Chicago: University of Chicago Press.

Frederking, Brian. 2003. Constructing Post-Cold War Collective Security. American Political Science Review 97(3): 363-378.

Goh, Evelyn. 2005a. Betwixt and Between: Southeast Asian Strategic Relations with the US and China, Institute of Defence and Strategic Studies Monograph 7. Singapore: Institute of Defence and Strategic Studies.

Goh, Evelyn. 2005b. Great Powers and Southeast Asian Regional Security Strategies: Omni-Enmeshment, Balancing and Hierarchical Order, Institute of Defence and Strategic Studies Working Paper 84. Singapore: Institute of Defence and Strategic Studies.

Goh, Evelyn. 2007-2008. Great Powers and Hierarchical Order in Southeast Asia: Analyzing Regional Security Strategies. International Security 32(2): 113157.

Goh, Evelyn. Institutions and the Great Power Bargain in East Asia: ASEAN's Limited 'Brokerage' Role. International Relations of the Asia-Pacific 11: 
373-401.

Gordon, Bernard K. 1966. The Dimensions of Conflict in Southeast Asia. Englewood Cliffs: Prentice-Hall.

Gordon, Bernard K. 1969. Toward Disengagement in Asia: A Strategy for American Foreign Policy. Englewood Cliffs: Prentice-Hall.

Hadiz, Vedi R. ed. 2006. Empire and Neoliberalism in Asia. London and New York: Routledge.

Horn, Robert C. 1985. Southeast Asian Perceptions of US Foreign Policy. Asian Survey 25(6): 678-691.

Huxley, Tim. 1996. Southeast Asia in the Study of International Relations: The Rise and Decline of a Region. The Pacific Review 9(2): 199-228.

Jorgensen-Dahl, Arnfinn. 1982. Regional Organization and Order in South-East Asia. London: Macmillan.

Khoo, Nicholas and Michael L. Smith. 2002. The Future of American Hegemony in the Asia-Pacific: A Concert of Asia or a Clear Pecking Order? Australian Journal of International Affairs 56(1): 65-81.

Kim, Jae Chol. 2010. Politics of Regionalism in East Asia: The Case of the East Asia Summit. Asian Perspectives 34(3): 113-136.

Komori, Yasumasa. Asia's Institutional Creation and Evolution. Asian Perspective 33(3): 151-182.

Lake, David A. 2006. American Hegemony and the Future of East-West Relations. International Studies Perspectives 7(1): 23-30.

Leifer, Michael. 1980. Conflict and Regional Order in South-East Asia, Adelphi Paper 162. London: International Institute for Strategic Studies.

Leifer, Michael. 1989. ASEAN and the Security of South-East Asia. London and New York: Routledge.

Levi, Werner. 1968. The Challenge of World Politics in South and Southeast Asia. Englewood Cliffs: Prentice-Hall.

Limaye, Satu P. 2004. Minding the Gaps: The Bush Administration and USSoutheast Asia Relations. Contemporary Southeast Asia 26(1): 73-93.

Mahapatra, Chintamani. 1990 American Role in the Origin and Growth of ASEAN. New Delhi: ABC Publishing House, 1990.

Mansfield, Edward D. and Helen V. Milner. 1999. The New Wave of Regionalism. International Organization 53(3): 589-627.

McMahon, Robert J. 2004. The United States and Southeast Asia in an Era of Decolonization, 1945-1965. In The Transformation of Southeast Asia: International Perspectives on Decolonization, eds. Marc Frey, Ronald W. Pruessen, and Tan Tai Yong. Singapore: Singapore University Press.

Murphy, Alexander B. 1991. Regions as Social Constructs: The Gap Between Theory and Practice. Progress in Human Geography 15(1): 22-35.

Onuf, Nicholas. 1997. A Constructivist Manifesto. In Constituting International 
Political Economy, eds. Kurt Burch and Robert A. Denemark. Boulder and London: Lynne Rienner.

Pollard, Vincent K. 1970. ASA and ASEAN, 1961-1967: Southeast Asian Regionalism. Asian Survey 10(3): 244-255.

Simon, Sheldon W. 1982. The ASEAN States and Regional Security. Stanford: Hoover Institution Press.

Simon, Sheldon W. 1983. Davids and Goliaths: Small Power-Great Power Security Relations in Southeast Asia. Asian Survey 23(3): 302-315.

Therborn, Goran. 2006. The Pole and the Triangle: US Power and the Triangle of the Americas, Asia and Europe. In Empire and Neoliberalism in Asia, ed. Vedi R. Hadiz. London and New York: Routledge.

Thomas, Nicholas. 2009. Understanding Regional Governance in Asia. In Governance and Regionalism in Asia, ed. Nicholas Thomas. New York: Routledge.

Tyner, James. 2007. America's Strategy in Southeast Asia: From the Cold War to the Terror War. New York: Rowman and Littlefield.

Vayrynen, Raimo. 2003. Regionalism: Old and New. International Studies Review 5(1): 25-51.

Weatherbee, Donald E. 1978. US Policy and the Two Southeast Asias. Asian Survey 18(4): 408-421.

Webber, Douglas. 2010. The Regional Integration that Didn't Happen: Cooperation Without Integration in Early Twenty-First Century East Asia. The Pacific Review 23(3): 313-333.

Wendt, Alexander. 1987. The Agent-Structure Problem in International Relations Theory. International Organization 41(3): 335-370.

Wendt, Alexander. 1992. Anarchy is What States Make of It: The Social Construction of Power Politics. International Organization 46(2): 391-425.

Wendt, Alexander. 1999. Social Theory of International Politics. Cambridge: Cambridge University Press.

Wight, Colin. 1999. They Shoot Dead Horses Don't They? Locating Agency in the Agent-Structure Problematique. European Journal of International Relations 5(1): 109-142.

Wight, Colin. 2006. Agents, Structures and International Relations: Politics as Ontology. Cambridge: Cambridge University Press.

Wu, Xinbo. 2009. Chinese Perspectives on Building an East Asian Community in the Twenty-First Century. In Asia's New Multilateralism: Cooperation, Competition, and the Search for Community, eds. Michael J. Green and Bates Gill. New York: Columbia University. 